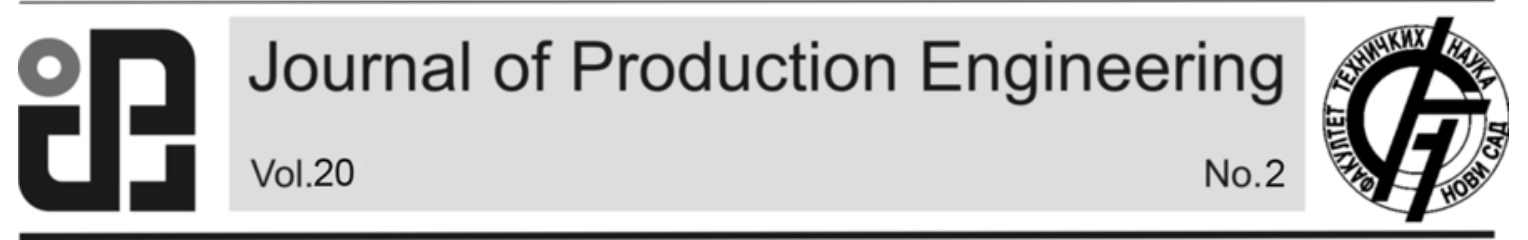

JPE (2017) Vol.20 (2)

Boca, M. L., Kovač, P., Savković, B.

Original Scientific Paper

\title{
MODEL APPROCH OF AUTOMATION OF BOTTLING AND PACKAGING FOR INDUSTRIAL PROCESS OF BOTTLES
}

Received: 02 September 2017 / Accepted: 26 November 2017

\begin{abstract}
Industry automation becomes the global trend in manufacturing, packaging process and is one of the most uses in industry; more and more companies are switching to automation. This reasearch is devoted to the use of automatic control system in process machine system; the control system will play a major role in control on all parts of this reasearch. This study report is about design and fabricate an automated packaging machine system The process of bottling and packaging of bottles is only partial part of automate process in one industrial process. Maked was a model using PetriNets for monitoring the process of bottling and packaging and we simulate a model for automation the step of bottling and packaging in the industrial process.
\end{abstract}

Key words: automatization; control; process

Modelski pristup automatizacije flaširanja i pakovanja u industrijskom procesu flaširanja. Automatizacija industrije postaje globalni trend u proizvodnji, procesu pakovanja i jedna je od najtraženijih upotreba u industriji; sve više kompanija prelazi na automatizaciju. Ovo istraživanje posvećeno je korištenju automatskog sistema upravljanja u procesnom mašinskom sistemu; kontrolni sistem će igrati glavnu ulogu u kontroli na svim delovima ovog istraživanja. Ova studija je o projektovanju i izradi automatizovanog sistema mašina za pakovanje. Proces flaširanja i pakovanja boca je samo deo automatskog procesa u jednom industrijskog procesu. Izrađen je model koristeći PetriNets za praćenje procesa flaširanja i pakovanja i simuliran model automatizacije faze flaširanja $i$ pakovanja $\mathrm{u}$ industrijskom procesu.

Ključne reči: automatizacija; kontrola; proces

\section{INTRODUCTION}

In the typical systems the model usually does not become an issue either because we will not have a large concurrent number or because our computers are really fast.

Development of society has been conditioned in times with the level and evolution of technologies used to produce goods consumer and goods capital. Big scientific discoveries and inventions of the last century revolutionized and propelled a spectacular economic and social life. It is enough to mention the main achievements in science and technologies (nuclear fission material synthesis substitution - elastomers, fibers, plastics, fertilizers, semiconductors and integrated circuits, biotechnology etc.) to understand that they are the basis of the present and future industrial.

Industry automation becomes the global trend in manufacturing, packaging process and is one of the most uses in industry; more and more companies are switching to automation. This research is devoted to the use of automatic control system in process machine system; the control system will play a major role in control on all parts of theresearch. This study report is about design and fabricate an automated packaging machine system [1].

Packaging machines (Fig. 1) are a vital part of the production process in the consumer goods industry. They often work in multishift operation, and any malfunctions have to be repaired quickly. Proven automation technology provides clear diagnostic and service strategies, and a partner with a global presence can offer prompt on-site support.

High speed is also one important characteristics of packaging machines, and the upper limit for this feature is more linked with the properties of the objects to be wrapped then to the real limits of the mechanism [2].

\section{DESCRIPTION OF THE INDUSTRIAL PROCESS}

Currently, in the industrial process of packaging and bottling of bottles, only Zone 1 and Zone 2 are fully automated process, Zone 3, needing at least 12 operators (Fig. 2). To increase productivity and decrease costs in this area, we observed the need to develop a project to streamline packaging by complete automation. It is required to be achieved by reconfiguring the master cases are transferred to the introduction in the final packaging and palletizing packs.

Given the above, the following requirements have been defined design:

- Transfer the boxes is automated packaging equipment

- The transfer is automatic storage boxes

- Sealing is automatic boxes

- Transfer the pallets are automatically palletizing area

- Transfer storage boxes, packaged and sealed, is automatic

- Palletizing is done automatically 


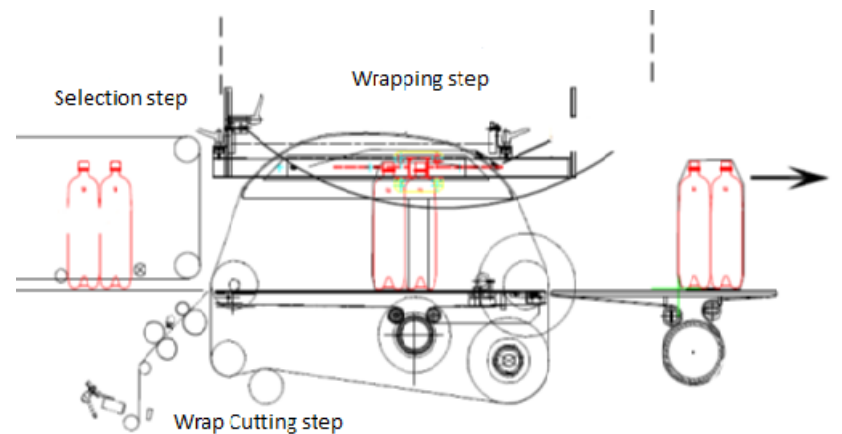

Fig. 1. The process of selection and wrapping for the bottles
To simulate automation solution suggested we used two ways:

- Monitoring technology using Petri networks

- Programming solution, with simulation for automation process in FlexSim.

For the two mentioned steps we followed these steps:

- Identifying required simulation

- Bonding using connections

- Programming each element

- Running the simulation

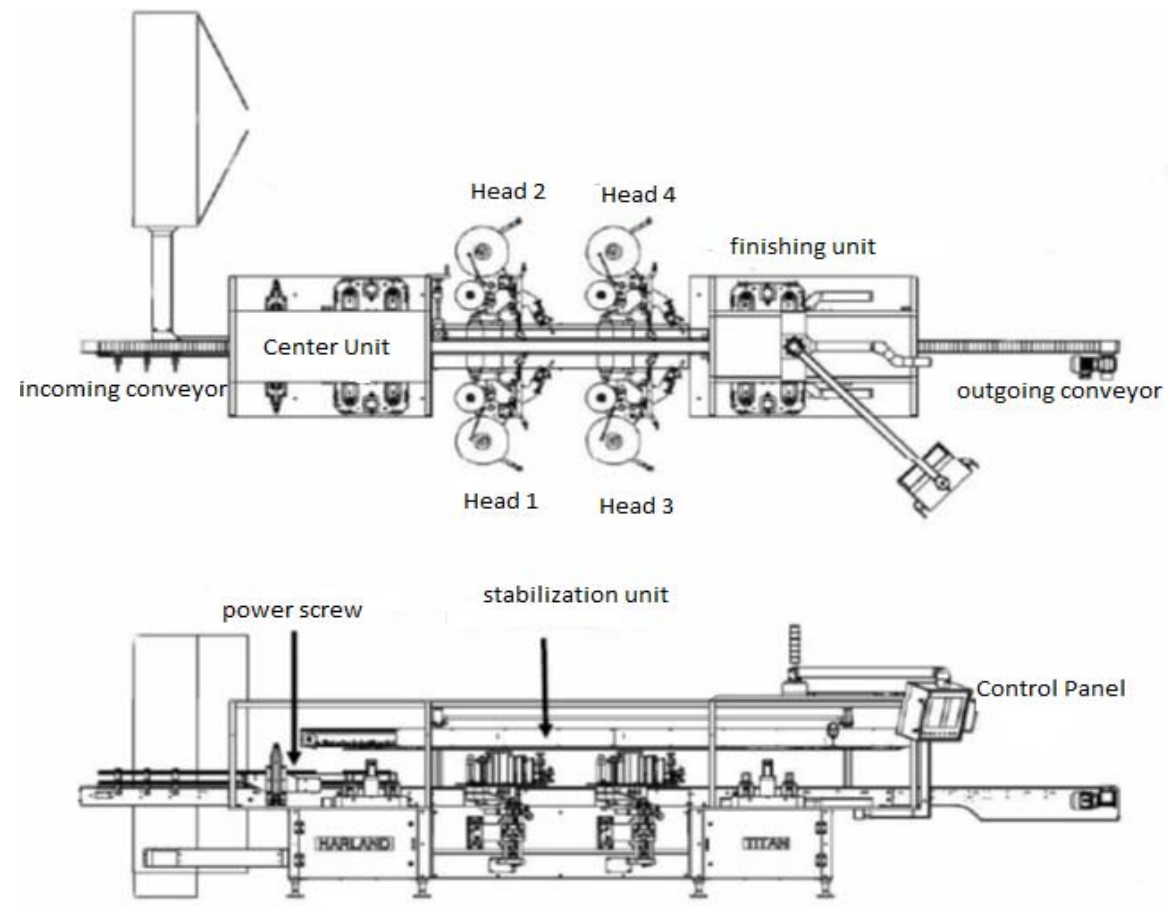

Fig. 2 The componets of the industrial process

Conducting of any technological process involves several elements: raw materials, equipment (plant), energy related technology and manufacturing personnel.

On the other hand, the efficiency of processes is influenced not only by technological factors present, but also a number of economic factors concerning both the costs of raw materials and energy and the selling price of products results, all depending on the economic situation in one time.

To obtain permanent businesses have a positive economic effect to prospect the market and to adapt their technological processes (consumption of materials and energy, working parameters) depending on the quality, accessibility and cost of their raw materials.

So, a technology that aims to obtain a product is subject to a number of technological and economic factors, expressed through physical inputs and outputs, energy and informational materials called variable processes. Calculation and their interdependence are expressed by mathematical relationships mathematical modeling of processes and optimize their default [3].

Since most processes can be achieved by several methods or technological options, perform thorough technical and economic analysis on investment costs, production costs and social and economic effects of each technical ways. It requires choosing the optimal technology, working and economical conditions more accessible as low as possible.

Optimal is to obtain top quality products, the maximum amount possible, with the lowest possible cost, in terms of maximum efficiency.

\section{MODEL USING PETRINETS FOR MONITORING THE PROCESS OF BOTTLING AND PACKAGING}

As a first step in process automation was achieved technological packing boxes process using PetriNets. These PetriNets had as purpose transport flow optimization of industrial process studied.

Tracking and optimization stages using Petri is in the design / prototyping process technology.

For simulation was used Visual Object Net ++, which was the whole process of packing boxes in preparation boxes or parts for assembly by putting boxes on pallets and storage boxes. 
Using this technique tracking packaging process, namely Petri nets, it may consider reducing the space and layout modification work equipment.

In Fig. 3. and Fig. 4. it is the technological process of packing boxes of bottles, using the constraints of time required for each stage and use two robots in different stages of work.

Representation describes the process before and during runtime $[4,5]$.

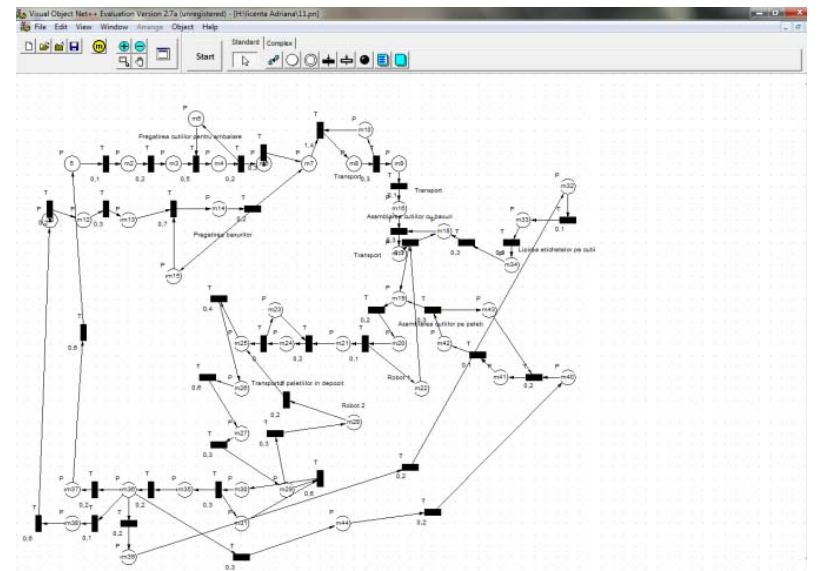

Fig. 3. Reprezentation of technological Flux using PetriNets

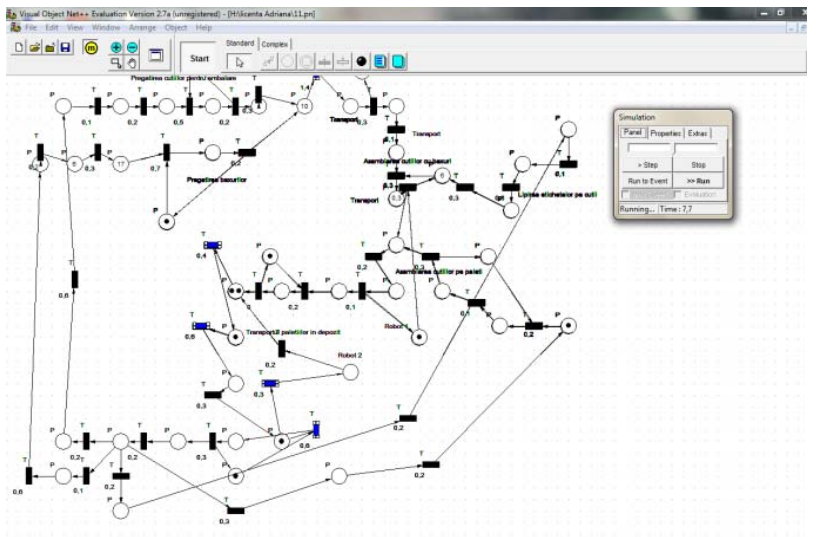

Fig. 4. Reprezentation of technological Flux using PetriNets

In Fig. 5. is the technological flow diagrams relating to the time working for the two robots and assembly stage boxes with boxes. It barely visible stream is linear, so there are no major changes in the technological flow.

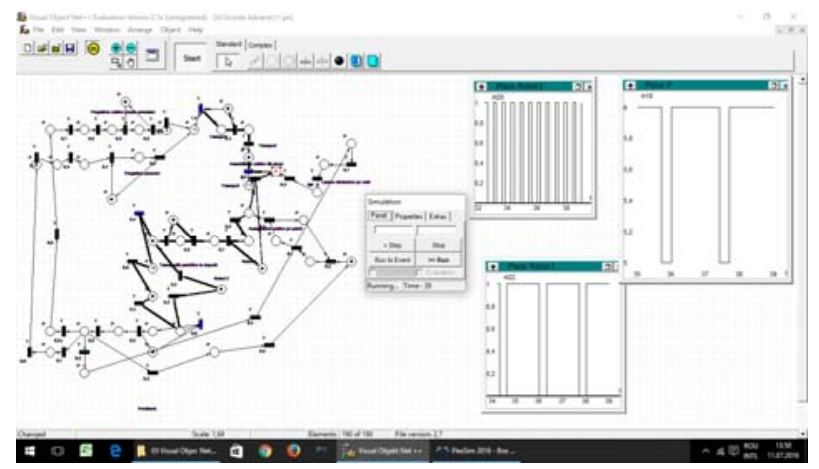

Fig. 5. Tracking and optimization of technological assembly process

\section{SIMULATION OF AUTOMATION IN THE PROCESS OF BOTTLING AND PACKAGING USING FLEXSIM}

For the automatically cases transferred packaging, storage boxes will be installed two conveyor belts. At the end of the first bands will be connected a lift that will transfer to the second conveyor belt master cases (Fig.6).

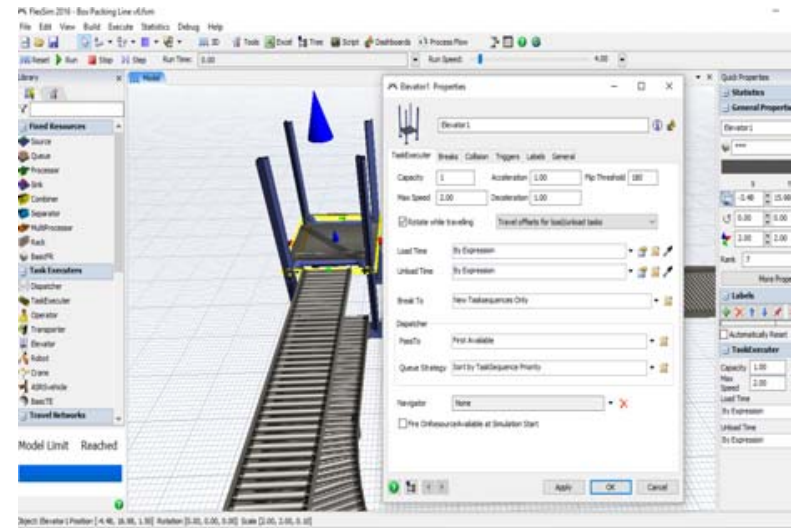

Fig. 6. Parameters setting for Elevator. Preparing the packing boxes

This, in turn, will transfer to the master cases packing boxes.

The pallets needed palletizing area have the same route as master cases until the elevator, with the same settings (Fig. 3.) will transferring the pallets using a third conveyor.

This will ensure the transfer of pallets in palletizing zone.

Also, for the preparation of storage boxes (Fig. 7.) will be install a utility that prepares the boxes, for provide boxes in the packaging using another conveyor.

Packing area will consist of a robot arm (Fig. 10 ).

Here will be introducing in each storage box one box of water. It is then transported in step sealing and labeling of boxes. Sealed storage boxes are transported to the palletizing area through a conveyor cylinder (Fig. 9).

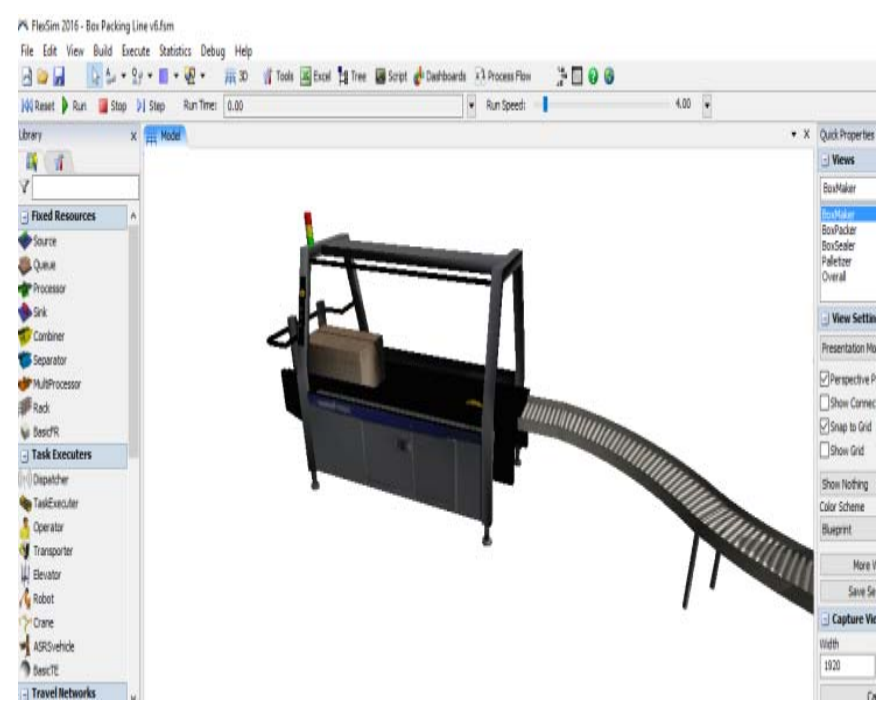

Fig. 7. Preparing of boxes 


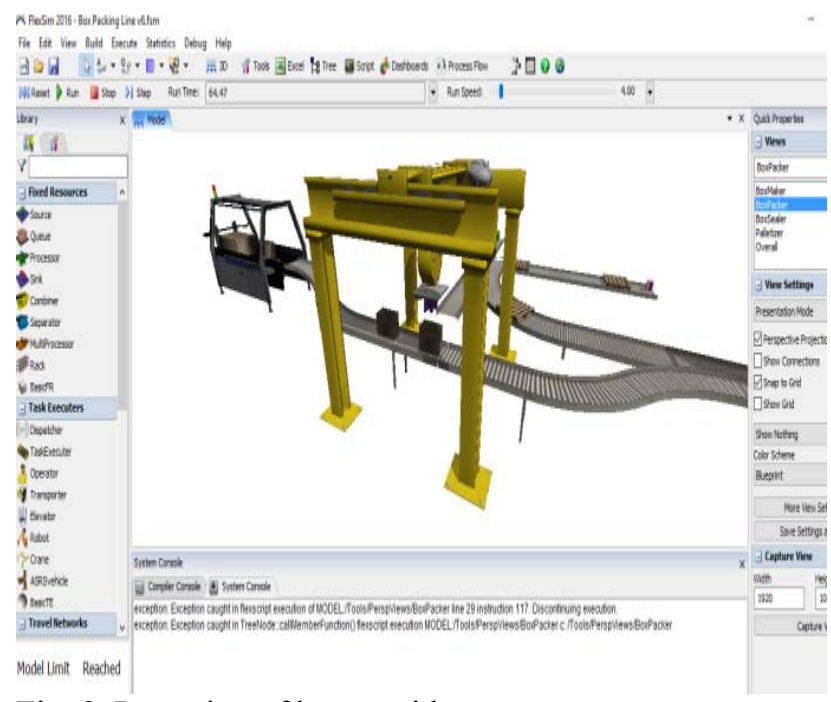

Fig. 8. Preparing of boxes with crane

Palletizing area is driven by a robotic arm that puts on each pallet, a total of 12 storage boxes (Fig.10.).

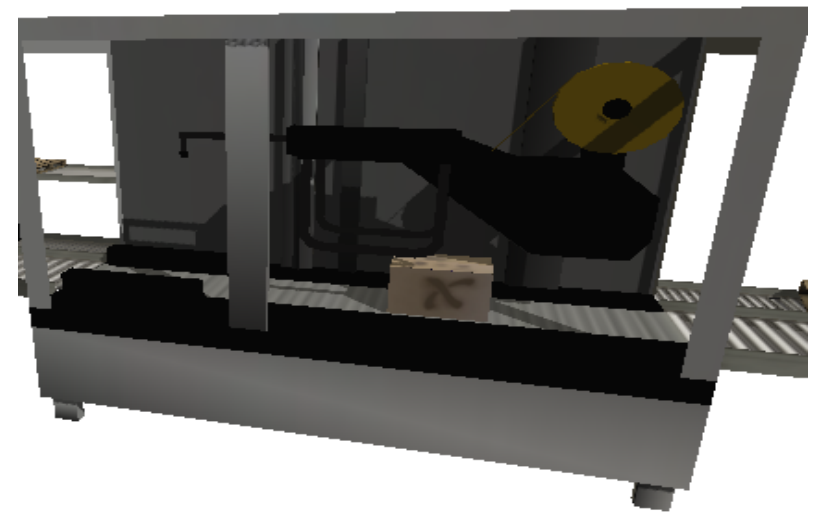

Fig. 9. Sealing of boxes

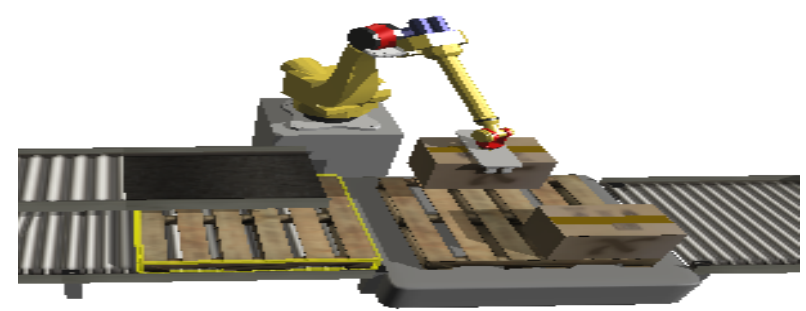

Fig.10. Palletizing robot arm

Take in case the analysis of the following two images (Fig. 11. and Fig. 12) we find major difference between this initial simulation stages through full automation and improved version $[6,7]$.

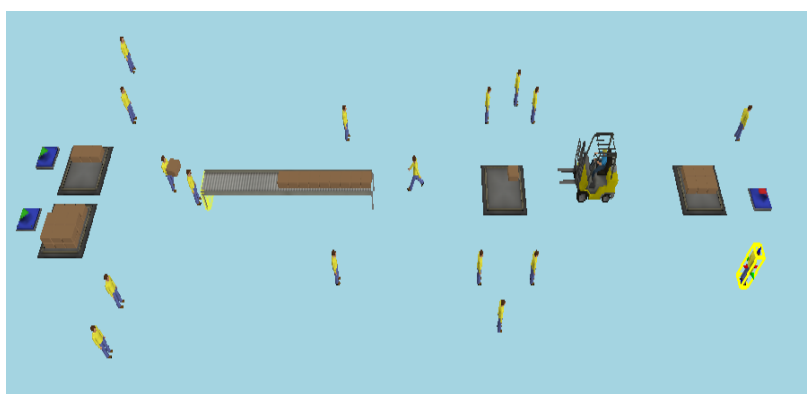

Fig. 11. FlexSim Simulation in initial case

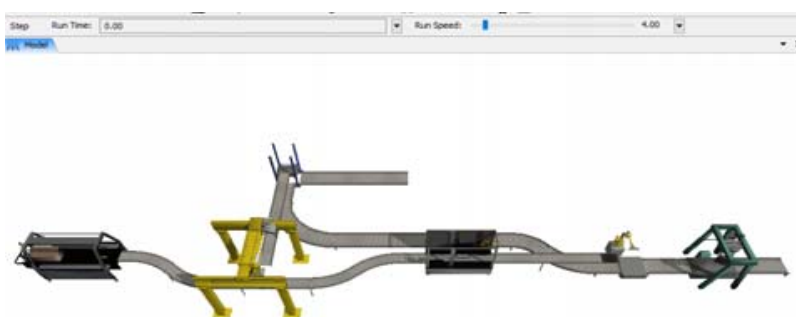

Fig. 12. FlexSim Simulation in final case after automation

\section{CONCLUSIONS}

Was performed in detail the packaging process flow, by setting specific time in each stage, and thus optimize the process.

Was made the automation packaging stage, initially at certain stages is made by the operator.

There is the possibility of using the model created in other processes involving packaging.

\section{REFERENCES}

[1] Alhade A. Algitta, Mustafa S., Ibrahim F., Abdalruof N.,Yousef M.: Automated Packaging Machine Using PLC, Control Engineering Dep., College of Electronic Technology, Bani Walid 38645, Libya, 2015

[2] Coulouris G., Dollimor., J, Kindberg T.: Distributed system: concept and design, 3rd edition, AddisonWesley, 772, 2001.

[3] Coulouris G., Dollimore J., Kindenberg T. : Distributed system: concept and design", E3 Addison-Wesley, 2002.

[4] Gupta V.: Distributed estimation and control in networked systems, California Institute of Technology Pasadena, California 2006.

[5] Jack H.: Automation manufacturing systems- with plc's', 2005.

[6] Vânătoru M.: Conducerea automata a proceselor industriale, Seria Control Engineering, Vol 1, 2001.

[7] Vişan S., Ghiga C., Panduru V.: Tehnologii industriale", Bucureşti, Editura ASE, 2000.

Autors: PhD Lecturer Boca Maria Loredana "1 Decembrie 1918" University of Alba Iulia, Romania, Alba Iulia, Gabriel Bethlen No.5, 510009, Phone.: +40 258-80613

Professor Pavel Kovac PhD, Assist. Professor Borislav Savkovic PhD, University of Novi Sad, Faculty of Technical Sciences, Institute for Production Engineering, Trg Dositeja Obradovica 6, 21000 Novi Sad, Serbia, Phone.: +381 21 450-366, Fax: +381 21 454-495.

E-mail: loredana_boca1@yahoo.com pkovac@uns.ac.rs savkovic@uns.ac.rs 